\title{
Parasites of the Flatfish Paralichthys adspersus (Steindachner, 1867) (Pleuronectiformes) from Northern Chile
}

\author{
Marcelo E Oliva/ ${ }^{+}$, Raúl E Castro*, Rodrigo Burgos* \\ Instituto de Investigaciones Oceanologicas * Departamento de Acuicultura, FAREMAR, Universidad de \\ Antofagasta, Casilla Postal 170, Antofagasta, Chile
}

Three species of protistan and 22 species of metazoan parasites were obtained from a sample of 179 flatfish, (Paralichthys adspersus) taken-off Antofagasta, northern Chile. Prevalence of infection of seven parasites (Protista: 1, Copepoda: 2, Digenea: 1, Acantocephala: 1, Nematoda: 2) was significantly and positively correlated with host size. Host's sex do not seem to affect prevalence of infection, except for Nybelinia surmenicola, Capillaria sp. and Anisakis sp. (prevalence of infection significantly greater in males than females) and Philometra sp. (prevalence higher in females). Mean abundance is correlated with size in nine species (Protista: 1, Copepoda: 2, Digenea: 3, Acantocephala: 1, Nematoda: 2). Host's sex do not affect mean abundance, except for Cainocreadium sp. and Philometra sp.(mean abundance higher in females) and Nybelinia surmenicola, Capillaria sp. and Anisakis sp. (mean abundance higher in males).

Key word: parasites - marine fishes - ecology - northern Chile

Paralichthys adspersus is a flatfish inhabiting the Pacific coast of South America, from Paita (northern Perú) to Lota (central Chile) (Chirichigno 1974). Parasite fauna of $P$. adspersus, like other flatfishes from Chile is poorly known. Currently, the copepods Lepeophtheirus edwardsii Castro \& Baeza, 1980 and Neobrachiella paralichthyos Castro \& Baeza 1986 are the only known parasites of this fish in Chilean waters. The objective of this study is to examine the impact of host's sex and size on some demographic characteristics of the infection, such as prevalence and abundance.

\section{MATERIALS AND METHODS}

A total of 179 flatfish were collected between April 1993 and June 1994 from sandy beaches near Antofagasta $\left(23^{\circ} 24^{\prime} \mathrm{S} 70^{\circ} 36^{\prime} \mathrm{W}\right)$ with gill nets, beach seine, or hand line. Fishes were carried to laboratory, dissected, and examined for ecto and endoparasites. Each fish was measured (total length to nearest $\mathrm{mm}$ ) and the sex was determined. A record of parasites (species, number and location in host) for each fish was made. Quantification of protistan was made according to an empirical scale obtained from the average of counts of spores in at

Supported by DINV - Universidad de Antofagasta ${ }^{+}$Corresponding author. Fax: 56-55-24.7542

Received 8 August 1995

Accepted 29 January 1996 least five fields of a microscope at 400 magnifications: 1 (less 5 spores), 2 (6 to 10 spores) and 3 (more than 11 spores). An ANOVA was performed to test if mean size of male and female flatfishes were significantly different. The Mann-Whitney "U" test and the log-likelihood "G" test were performed to evaluate if abundance and prevalence of infection were affected by host's sex, respectively. Finally, the Spearman correlation coefficient was calculated to evaluate if mean abundance and prevalence are affected by host's sex. Significance was considered at $\alpha=0.05$. Statistical analysis follows Willkinson (1990). Ecological terminology follows Margolis et al. (1982)

\section{RESULTS}

One hundred and seventy six flatfish were analyzed. The size of three fishes could not be accurately determined because injuries in the tail, thus those fishes were eliminated from quantitative but not qualitative analysis. Females were significantly greater than males (females $34.2 \mathrm{~cm}$, males 31.2 $\mathrm{cm} \mathrm{F}=12.79, \mathrm{GL}=1,174, \mathrm{P}<0.001)$. Twenty five parasitic species were obtained (Protista: 3, Metazoan: 22). Parasite species, developmental stages, location in host body, prevalence and mean abundance are presented in Table I. Statistical analysis were performed only for those parasites considered common (prevalence of infection $\geq 5 \%$ ). Values of Spearman correlation coefficients for the relation size-abundance (Table II) show positive 
TABLE I

Parasites, developmental stage, location in the host, prevalence and mean abundance

\begin{tabular}{|c|c|c|c|c|}
\hline Parasite & Stage & Location & Prevalence & $\begin{array}{c}\text { Mean } \\
\text { abundance }\end{array}$ \\
\hline \multicolumn{5}{|l|}{ PROTISTA } \\
\hline Ceratomyxa sp. & T P S & $\mathrm{Gb}$ & 67.9 & 0.79 \\
\hline Sinuolinea sp. & T P S & $\mathrm{Ub}$ & 48.2 & 0.58 \\
\hline Chloromyxum sp. & T P S & $\mathrm{Ub}$ & 11.3 & 0.13 \\
\hline \multicolumn{5}{|l|}{ Monogenea } \\
\hline Entobdella hippoglossi & A & Bs & 3.4 & 0.06 \\
\hline \multicolumn{5}{|l|}{ Copepoda } \\
\hline Lepeophtheirus edwardsii & A C & Bs G & 18.8 & 0.43 \\
\hline Neobrachiella paralichyos & A & G Mo & 8.0 & 0.17 \\
\hline Bomolochus sp. & A & Mo G O & 2.1 & 0.05 \\
\hline Chondracanthus psetti & A & Mo G & 12.5 & 0.18 \\
\hline \multicolumn{5}{|l|}{ Isopoda } \\
\hline Aeglidae gen. sp. & A & Mo & 2.3 & 0.02 \\
\hline \multicolumn{5}{|l|}{ Annelida } \\
\hline Hirudinea gen sp. & A & Bs & 2.1 & 0.01 \\
\hline \multicolumn{5}{|l|}{ Digenea } \\
\hline Cainocreadium sp. & A & In Pc & 54.5 & 3.96 \\
\hline Prosorhynchus sp. & A & In Pc & 18.2 & 3.12 \\
\hline Opecoelidae & M & G Cc S & 21.6 & 1.7 \\
\hline \multicolumn{5}{|l|}{ Eucestoda } \\
\hline Pseudophyllidea gen. sp. & A & In & 4.5 & 0.07 \\
\hline Nybelinia surmenicola & $\mathrm{L}$ & $\mathrm{Cc} \mathrm{Mu} \mathrm{G}$ & 9.1 & 0.12 \\
\hline Scolex pleuronectis & $\mathrm{L}$ & In & 5.7 & 0.29 \\
\hline Lacistorhynchus dollfussi & $\mathrm{L}$ & $\mathrm{Mu} \mathrm{G} \mathrm{Cc}$ & 8.0 & 1.58 \\
\hline \multicolumn{5}{|l|}{ Acantocephala } \\
\hline Corynosoma australis & $\mathrm{L}$ & In $\mathrm{S} \mathrm{Cc}$ & 56.3 & 11.37 \\
\hline Unidentied Acantocephala & A & In & 0.56 & 0.006 \\
\hline \multicolumn{5}{|l|}{ Nematoda } \\
\hline Anisakis physeteris & $\mathrm{L}$ & $\mathrm{Mu} \mathrm{Cc}$ & 2.1 & 0.01 \\
\hline Capillaria sp. & A & $\mathrm{S}$ & 18.8 & 2.37 \\
\hline Philometra sp. & A & Go & 17.6 & 0.57 \\
\hline Pseudoterranova decipiens & $\mathrm{L}$ & $\mathrm{Mu} \mathrm{Cc}$ & 9.1 & 0.26 \\
\hline Hysterothylacium sp. & $\mathrm{L}$ & $\mathrm{S}$ & 1.7 & 0.05 \\
\hline Anisakis sp. & $\mathrm{L}$ & In $\mathrm{S}$ & 16.5 & 0.33 \\
\hline
\end{tabular}

T: trophozoite, P: plasmodia, S: spore, A: adult, L: larvae, C: chalimus, M: metacercariae, Gb: gall-bladder, Ub: urinary bladder, Bs: body surface, G: gills, Mo: mouth, Go: gonads, O: operculum, In: intestine, Pc: piloric caeca, Cc: coelomic cavity, $\mathrm{S}$ : stomach, $\mathrm{Mu}$ : muscle

and significant correlation only for the protista Ceratomyxa sp., the copepods, L. edwardssi and Ch. psetti, the digeneans, Cainocreadium sp. and Prosorhynchus sp., the Acanthocephala, C. australis and the nematodes $P$. decipiens and Anisakis sp. Table II also shows values of the Spearman correlation coefficient for the relation between prevalence and mean host size. Prevalence is positively and significantly correlated with size only for the following parasites: Ceratomyxa sp., $L$. edwardssi, Ch. psetti, Cainocreadium sp., Opecoelidae (Metacercariae), C. australis, $P$. decipiens and Anisakis sp.

Table III shows values of the $\chi^{2}$ approximation to the Mann-Whitney "U" test. The hypothesis of effect of the sex on mean abundance was not rejected for the following five species: Cainocreadium sp., Prosorhynchus sp. and 
TABLE II

Effect of host size on mean abundance and prevalence of infection

\begin{tabular}{|c|c|c|c|c|}
\hline & \multicolumn{2}{|c|}{ Mean abundance $^{a}$} & \multicolumn{2}{|c|}{ Prevalence $^{b}$} \\
\hline & $\mathrm{r}$ & $\mathrm{p}$ & $\mathrm{r}$ & $\mathrm{p}$ \\
\hline Ceratomyxa sp. & .32 & $\mathrm{P}<0.001$ & 0.98 & $0.001>\mathrm{P}$ \\
\hline Sinuolinea sp. & .09 & $P>0.20$ & 0.69 & $0.20>\mathrm{P}>0.10$ \\
\hline Chloromyxum sp. & -.097 & $\mathrm{P}>0.10$ & 0.44 & $0.50>\mathrm{P}>0.20$ \\
\hline L. edwardsii & .28 & $\mathrm{P}<0.001$ & 0.91 & $0.02>\mathrm{P}>0.01$ \\
\hline N. paralychthyos & .05 & $\mathrm{P}>0.50$ & 0.55 & $0.50>P>0.20$ \\
\hline C. psetti & .22 & $P<0.005$ & 0.94 & $0.01>\mathrm{P}>0.005$ \\
\hline Cainocreadium sp. & .28 & $\mathrm{P}<0.001$ & 0.89 & $0.02>\mathrm{P}>0.01$ \\
\hline Prosorhynchus sp. & .25 & $\mathrm{P}<0.001$ & 0.75 & $0.10>\mathrm{P}>0.05$ \\
\hline Opecoelidae & .12 & $\mathrm{P}>0.10$ & 0.92 & $0.01>\mathrm{P}>0.005$ \\
\hline N. surmenicola & .07 & $\mathrm{P}>0.20$ & 0.81 & $0.10>\mathrm{P}>0.05$ \\
\hline S. pleuronectis & -.082 & $\mathrm{P}>0.20$ & 0.13 & $\mathrm{P}>0.5$ \\
\hline L. dollfusi & -.028 & $\mathrm{P}>0.50$ & 0.54 & $0.5>\mathrm{P}>0.20$ \\
\hline C. australis & .38 & $P<0.001$ & 0.88 & $0.05>\mathrm{P}>0.02$ \\
\hline Capillaria sp. & -.121 & $\mathrm{P}>0.10$ & 0.7 & $0.20>\mathrm{P}>0.10$ \\
\hline Philometra sp. & .05 & $\mathrm{P}>0.5$ & 0.23 & $\mathrm{P}>0.5$ \\
\hline P. decipiens & .16 & $\mathrm{P}<0.05$ & 0.83 & $0.05>\mathrm{P}>0.02$ \\
\hline Anisakis sp. & .17 & $\mathrm{P}<0.05$ & 0.89 & $0.02>\mathrm{P}>0.01$ \\
\hline
\end{tabular}

r: Spearman correlation coefficient, p: probability, $a$ : degree of freedom $=166$ for protistan and 174 for metazoan, $b$ : degree of freedom $=4$ for all parasites

TABLE III

Effect of sex on abundance and prevalence of infection

\begin{tabular}{|c|c|c|c|c|}
\hline & \multicolumn{2}{|c|}{ Abundance } & \multicolumn{2}{|c|}{ Prevalence } \\
\hline & $\chi^{2}$ & $\mathrm{p}$ & $\mathrm{G}$ & $\mathrm{p}$ \\
\hline Ceratomyxa sp. & 0.73 & 0.39 & 0.34 & $0.75>\mathrm{P}>0.50$ \\
\hline Sinuolinea sp. & 1.1 & 0.3 & 2.33 & $0.25>\mathrm{P}>0.10$ \\
\hline Chloromyxum sp. & 0.1 & 0.74 & 0.12 & $0.75>\mathrm{P}>0.50$ \\
\hline L. edwardsii & 0.6 & 0.43 & 0.29 & $0.75>\mathrm{P}>0.50$ \\
\hline N. paralichthyos & 0.1 & 0.76 & 0.04 & $0.90>\mathrm{P}>0.75$ \\
\hline C. psetti & 0.2 & 0.63 & 0.21 & $0.75>\mathrm{P}>0.50$ \\
\hline Cainocreadium sp. & 3.9 & $(*)$ & 0.3 & $0.75>\mathrm{P}>0.50$ \\
\hline Prosorynchus sp. & 3.5 & 0.06 & 1.46 & $0.25>\mathrm{P}>0.10$ \\
\hline Opecoelidae (Metacercaria) & 1.1 & 0.3 & 1.0 & $0.50>\mathrm{P}>0.25$ \\
\hline Nybelinia sp. & 4.0 & 0.04 & 3.88 & $0.05>\mathrm{P}>0.03$ \\
\hline S. pleuronectis & 0.9 & 0.33 & 0.9 & $0.50>\mathrm{P}>0.25$ \\
\hline L. dollfusi & 0.66 & 0.42 & 0.59 & $0.50>\mathrm{P}>0.25$ \\
\hline C. australis & 1.97 & 0.16 & 0.84 & $0.50>\mathrm{P}>0.25$ \\
\hline Capillaria sp. & 5.65 & 0.02 & 5.42 & $0.025>\mathrm{P}>0.01$ \\
\hline Philometra sp. & 13.18 & $(*)$ & 14.3 & $0.001>\mathrm{P}$ \\
\hline P. decipiens & 0.89 & 0.34 & 0.82 & $0.50>\mathrm{P}>0.25$ \\
\hline Anisakis sp. & 4.62 & 0.03 & 3.86 & $0.05>\mathrm{P}>0.025$ \\
\hline
\end{tabular}

$\chi^{2}$ : Chi-square aproximation to Mann-Whitney "U" test, G: value of the Log-likelihood "G” test, p: probability (*) $=<0.001$

Philometra sp. (with mean abundance greater in females than in males) and $N$. surmenicola and Capillaria (higher mean abundance in females). The same Table shows " $G$ " values that demonstrates the evidence of effect of host's sex on prevalence of infection for the following parasites: N. surmenicola, Capillaria sp. and Anisakis sp. with higher prevalence in males and Philometra sp. with prevalence in female greater than in males. 


\section{DISCUSSION}

As a rule, in all host species that have been accurately studied for parasites, infection changes with age (Rohde 1984). This is true for both qualitative and quantitative changes in the parasite fauna. As have been pointed by Polyansky (1961), as a fish grows, the diet normally changes and consequently, the fauna of trophically transmitted parasites will be replaced by new species of parasites. Quantitative differences in parasite infection between sex can be expected and are explained as a consequence of different habitat occupied by males and females, differences in the diet and/or physiology (Kennedy 1975). Our results show absence of a common pattern of infection for all the parasitic species. Prevalence of infection was significantly and positively correlated with size for the monoxenics Ceratomyxa sp., L. edwardsii, Ch. psetti, and the heteroxenics Cainocreadium sp., $C$. australis, $P$. decipiens, Anisakis sp. and metacercariae of an unidentified opecoelid. Abundance also increases with size for the same parasites and Prosorhynchus sp. but not for the opecoelid metacercaria. This means that, as fishes in the population grow, chances of infection increase for those parasites, due to a long period of exposition to free living infective stages of the monoxenic parasites and an increased use, as food, of the intermediate host of the heteroxenic parasites (Polyansky 1961, Rohde 1993). Sex affects mean abundance and prevalence only for six species, all of them are trophically transmitted parasites, this means that differences are due mainly to diet and or physiology, but no differences in habitat could be expected for male and female flatfishes, as suggested by the absence of differences in monoxenic parasites. Moreover, Kong et al. (1995) were unable to found differences in diet of male and females $P$. adspersus. Thus, differences in some ecological parameters of the infectious process could be a consequence of differential physiology of male and females flatfishes.

The characteristic of $P$. adspersus, when compared with other flatfishes, is the sparse of the parasite fauna. Table IV shows composition of the parasite fauna of some related fish, including complete and partial (only gastrointestinal parasites) parasitological analysis. Our data shows a poor digenea fauna, that is evident for the other chilean flatfish whose parasites are known. It has been demonstrated that digenea are good indicators of the diet of the host (Gaevskaya \& Kovaleva 1982) and acquisition of the parasite by a definitive host is a consequence of the ingestion of the intermediate host (mainly invertebrates) but a postcyclic parasitism (transference from fish to fish via predation) can also occur (Arthur \& Albert 1994). The bulk of the diet of $P$. adspersus in northern Chile are the anchovy Engraulis ringens, the silver side Austromenidia laticlavia and the sand crab Emerita analoga, that explain the $95 \%$ of the IRR (index of relative importance) (Kong et al. 1995). Parasites of $E$. ringens from Chile were studied by Riffo (1990) who was unable to found digenea (both larval or adult), there are not studies of parasites of $A$. laticlavia and parasites of the sand crab do not includes larval or adult digenea (Oliva et al. 1992). Thus the poor digenea fauna of $P$. adspersus can be a consequence of the monotonous diet (number of digenea species in flatfishes is not affected

TABLE IV

Number of parasites (by major taxonomic groups) in some related flatfish (Pleuronectiformes)

\begin{tabular}{lrrrrrrrrr}
\hline & $\mathrm{PV}$ & $\mathrm{HM}^{a}$ & $\mathrm{LP}$ & $\mathrm{HP}^{b}$ & $\mathrm{HH}^{b}$ & $\mathrm{RH}^{b}$ & $\mathrm{RH} 2$ & $\mathrm{RH} 3$ & $\mathrm{PA}$ \\
\hline Protista & 1 & 0 & 7 & 0 & 0 & 0 & 4 & 10 & 3 \\
Monogenea & 0 & 1 & 2 & 0 & 0 & 0 & 1 & 3 & 1 \\
Digenea & 10 & 1 & 9 & 7 & 16 & 11 & 18 & 28 & 3 \\
Cestoda & 1 & 3 & 1 & 1 & 3 & 3 & 6 & 9 & 4 \\
Acantocephala & 1 & 1 & 1 & 2 & 2 & 1 & 5 & 8 & 2 \\
Nematoda & 5 & 2 & 2 & 0 & 2 & 1 & 8 & 8 & 6 \\
Crustacea & 3 & 3 & 2 & 0 & 0 & 0 & 2 & 8 & 4 \\
Hirudinea & 1 & 0 & 1 & 0 & 0 & 0 & 1 & 2 & 1 \\
Sample size & 628 & 60 & 526 & 74 & 272 & 71 & 350 & $(*)$ & 179 \\
\hline
\end{tabular}

PV: Parophrys vetulus, HM: Hippoglossina macrops, LP: Liopsetta putnami, HP: Hippoglossoides platessoides, HH: Hippoglossus hippoglossus, RH: Reinhardius hippoglossoides, PA: Paralichthys adspersus. a: only metazoan studied, $b$ : only gastrointestinal studied. RH1: according to Scott \& Bray (1989), RH2: according to Arthur \& Albert (1994), RH3 (*): a checklist from Arthur \& Albert (1994) includes all the known parasites for $R$. hippoglossoides, References: Olson 1978, Burn 1980, Scott \& Bray 1989, Riffo 1991, Arthur \& Albert 1994, Siddall et al. 1994 
TABLE V

Number of digenean parasitic in marine fishes from the Peruvian faunistic province (only data on quantitative surveys are considered)

\begin{tabular}{llrll}
\hline Host species & ND & SS & GL & Author \\
\hline H. macrops & 1 & 60 & CC & Riffo 1991 \\
E. ringens & 0 & 70 & CC & Riffo 1990 \\
S. benticki & 0 & 50 & CC & Riffo 1990 \\
M. cephalus & 7 & 107 & CC & Fernandez 1987 \\
H. lengerichi & 4 & 30 & CC & George-Nascimento \& Iriarte 1989 \\
C. callorhynchus & 0 & 55 & CC & Fernandez et al.1986 \\
M. gayi & 3 & 140 & CP & Duran \& Oliva 1980 \\
M. australis & 2 & 100 & SC & Fernandez 1985 \\
G. chilensis & 1 & 80 & CC & Vergara \& George-Nascimento 1982 \\
T. murphy & 1 & 78 & NC & Oliva 1994 \\
P. peruanus & 1 & 124 & CP & Luque \& Oliva 1993 \\
S. minor & 1 & 311 & CP & Oliva et al. 1990 \\
M. ophicephalus & 1 & 237 & CP & Luque 1994 \\
\hline
\end{tabular}

ND: number of digenean species per host species, SS: sample size. GL: geographic locality (CP: central Perú, NC: northern Chile, CC: central Chile, SC: southern Chile)

by host sample size, $\mathrm{r}: 0.313,0.5>\mathrm{P}>0.20, \mathrm{df}=$ 6). The poor digenean fauna of fishes from the South Pacific coast of America (central and northern Chile and southern and central Perú) mainly influenced by the Peruvian cool current, is a characteristic of all the host-parasite system quantitatively studied to date (Table V). Unfortunately, no accurately studies at community levels of pelagic and benthonic communities are available from this area. Studies at community levels from this particular area must be done in order to evaluate the role of highly productive but unstable system such as the "upwelling eco-system" on the parasite fauna of fishes.

\section{REFERENCES}

Arthur JR, Albert E 1994. A survey of the parasites of Greenland halibut (Reinhardtius hippoglossoides) caught off Atlantic Canada, with notes on their zoogeography in this fish. Can J Zool 72: 765-778.

Burn PR 1980. The parasites of smooth flounder, Liopsetta putnami (Gill) from the Great Bay Estuary, New Hampshire. J Parasitol 66: 532-541.

Chirichigno N 1974. Clave para identificar los peces marinos del Perú. Inf. 44 IMARPE, Callao-Perú, $388 \mathrm{pp}$.

Duran LE, Oliva ME 1980. Estudio parasitológico en Merluccius gayi peruanus Ginsgburg, 1954. Bol Chile Parasit 35: 18-21.

Fernandez J 1985. Estudio parasitológico de Merluccius australis (Hutton, 1872) (Pisces: Merluccidae): Aspectos sistemáticos, estadísticos y zoogeográficos. Bol Soc Biol Concepción 56: 31-41.

Fernandez J 1987. Los parasitos de la lisa Mugil cephalus L., en Chile: Sistematica y aspectos poblacionales (Perciformes: Mugilidae) Gayana (Zool) 51: 3-58.
Fernandez J, Villalba C, Alvina A 1986. Parásitos del pejegallo Callorhynchus callorhynchus (L) en Chile: aspectos biológicos y sistemáticos. Biol Pesq 15: 6774.

Gaevskaya AV, Kovaleva AA 1982. The trematode fauna of Atlantic Trachurus and its special features. Gidrobiol Zhur 18: 60-65.

George-Nascimento M, Iriarte J 1989. Las infracomunidades de parásitos metazoos del chancharro Helicolenus lengerichi Norman, 1937 (Pisces: Scorpaenidae): Un ensamble no interactivo de especies. Rev Chile Hist Nat 62: 217-227.

Kennedy C 1975. Ecological animal parasitology. Blackwell Sc. Pub. London, 163 pp.

Kong I, Clarke M, Escribano R 1995. Alimentación de Paralichthys adspersus (Steindachner, 1867) en la zona norte de Chile. Rev Biol Mar 30: in press.

Luque JL 1994. Dinámica poblacional y estructura de la comunidad de metazoarios parasitos de Menticirrhus ophicephalus (Pisces: Sciaenidae) en la costa peruana. Rev Biol Trop 42: 21-29.

Luque JL, Oliva ME 1993. Análisis cuantitativo y estructura de la comunidad parasitaria de Paralonchurus peruanus (Pisces: Sciaenidae) en la costa peruana. Parasitol al Dia 17: 107-111.

Margolis L, Esch G, Holmes J, Kuris A, Schad G 1982. The use of ecological terms in parasitology (report of an ad-hoc committee of the American Society of Parasitologists) J Parasitol 68: 131-133.

Oliva ME 1994. Parasites of the Chilean jack mackerel Trachurus symmetricus murphyi (Pisces: Carangidae) Mem Inst Oswaldo Cruz 89: 363-364.

Oliva ME, Luque JL, Iannacone J 1990. The metazoan parasites of Stellifer minor (Tschudii,1844): an ecological approach. Mem Inst Oswaldo Cruz 85: 271274.

Oliva ME, Luque JL, Cevallos A 1992. Parasitos de 
Emerita analoga (Stimpson) (Crustacea): Implicancias ecológicas. Bol de Lima 79: 77-80.

Olson RE 1978. Parasitology of the english sole, Parophrys vetulus Girard in Oregon USA. J Fish Biol 13: 237-248.

Polyansky YI 1961. Ecology of parasites of marine fishes, p. 48-83. In VA Dogiel, GK Petruschenko, YI Polyansky (eds) Parasitology of fishes. Oliver \& Boyd, Edinburg.

Riffo R 1990. Primer registro parasitologico en Strangomera benticki (Normann, 1936) y Engraulis ringens Jennyns, 1842 (Pisces: Clupeiformes) para la costa de Chile. Medio Ambiente 11: 59-64.

Riffo R 1991. La fauna de parasitos metazoos del lenguado de ojos grandes Hippoglossina macrops Steindachner, 1876 (Pisces: Bothi-dae): Una aproximación ecológica. Medio Ambiente 11: 54-60.
Rohde K 1984. Ecology of marine parasites. Helgolander Meeresunters 37: 5-33.

Rohde K 1993. Ecology of marine parasites. (2 ed.), Univ. Queensland press, $245 \mathrm{pp}$.

Siddall R, Pike AW, MacVicar AH 1994. Parasites of flatfish in relation to sewage sludge dumping. J Fish Biol 45: 193-209.

Scott JS, Bray SA 1989. Helminth parasites of the alimentary tract of Atlantic halibut (Hippoglossus hippoglossus L.) and Greenland halibut (Reinhardtius hippoglossoides (Walbaum) on the Scotian shelf. Can J Zool 67: 1476-1481.

Vergara L, George-Nascimento M 1982. Contribución al estudio del parasitismo en el congrio colorado Genypterus chilensis (Guichenot, 1848). Bol Chile Parasit 37: 9-14.

Willkinson L 1990. SYSTAT: The system for statistics. Evanston, II SYSTAT inc, 560 pp. 